\title{
Ameliorative Effect of Resveratrol Against Histological Alterations in Lung of Mice Induced by Subchronic Exposure of Cigarette and Waterpipe Tobacco Smoking
}

\author{
Efecto Paliativo del Resveratrol Frente a las Alteraciones Histológicas en el Pulmón de \\ Ratones Inducidas por Exposición Subcrónica del Tabaquismo de Cigarrillos y Pipas de Agua
}

Ahmed A. Alzbeede ${ }^{1,2}$; Ziad A. Shraideh ${ }^{1}$ \& Darwish H. Badran ${ }^{3}$

ALZBEEDE, A. A.; SHRAIDEH, Z. A. \& BADRAN, D. H. Ameliorative effect of resveratrol against histological alterations in lung of mice induced by subchronic exposure of cigarette and waterpipe tobacco smoking. Int. J. Morphol., 39(1):11-17, 2021.

SUMMARY: This study aims to evaluate the ability of resveratrol (RSV) antioxidant to attenuate the oxidative stress condition induced by secondhand exposure of cigarettes and waterpipe smoking using animal model. Forty-eight mice were divided equally into six different groups, and RSV was delivered to certain groups intraperitoneally with a dose of $25 \mathrm{mg} / \mathrm{kg} / \mathrm{day}$. The process of smoking exposure was performed using a specialized smoking machine. The experiment duration lasts for six consecutive weeks. Five $\mu \mathrm{m}$ sections of lung were stained with hematoxylin and eosin for light microscopy, and $70 \mathrm{~nm}$ ultrathin sections of lung stained with uranyl acetate and lead citrate were prepared for transmission electron microscopy to observe the cellular ultrastructure. In lung, RSV reduced the deterioration and blebbing of bronchiole epithelium, reduced the inflammation, increased the surface area of alveolar sac, and reduced the thickening of alveolar walls. Also, blood vessels were less congested and less dilated with less diffusion of extravasated blood. Ultrastructural images illustrated that RSV protects the normal structure of alveolar septum, prevents DNA damage and alveolar degeneration, showed less degree of apical membrane blebbing and retained the uniform pattern of mitochondria. In conclusion, RSV has ameliorative effects against the oxidative stress condition induced by secondhand (side stream) exposure of cigarette and waterpipe tobacco smoking.

KEY WORDS: Antioxidant; Microscopy; Histopathology; TEM; Tobacco smoking.

\section{INTRODUCTION}

Tobacco smoking is associated with cellular oxidative damage and could increase the risk of cancer in various organs in human and animal studies (Khani et al., 2018). Chronic exposure to tobacco smoke containing irritant chemicals could induce chronic obstructive pulmonary disease (COPD), that could reduces the physiological actions of lungs. There are two common forms for COPD; emphysema and chronic bronchitis, which could impair the physiology of lung during respiration process (Yoshida \& Tuder, 2007). Tobacco smoke induces oxidative stress in mammals through increasing level of reactive oxygen species (ROS) and reactive nitrogen species (RNS) that generate free radicals which may develop to initiate tumor formation that could evolve into cancer (Dreher \& Junod, 1996). Reactive molecules "free radicals" can damage tissues by reacting with critical sulfhydryl bonds in proteins, nucleotides in deoxyribonucleic acid (DNA) and polyunsaturated fatty acids in cellular membranes. Free radicals can originate endogenously from normal metabolic reactions or exogenously as components oftobacco smoke, exposure to radiations, air pollutants and through the metabolism of certain drugs, industrial solvents and pesticides (Phaniendra et al., 2015).

Antioxidants are chemicals able to inhibit or suppress the action of free radicals, therefore these chemicals could lower the risk of oxidative stress and preserve the biomolecules of the cells from modifications and damages. Resveratrol (RSV) is 3,5,4' trihydroxystilbene with molecular formula C14H12O3 and molecular weight 228.24 $\mathrm{g} / \mathrm{mol}$. It is classified as an exogenous antioxidant compound extracted from plants and has numerous beneficial

\footnotetext{
${ }^{1}$ Department of Biological Sciences, School of Science, The University of Jordan, Amman, Jordan.

${ }^{2}$ Department of Medical Laboratory Science, College of Science, Komar University of Science and Technology, Sulaymaniyah, Kudistan Region, Iraq.

${ }^{3}$ Department of Anatomy and Histology, School of Medicine, The University of Jordan, Amman, Jordan.
} 
chemophysiological activities in mammalian organisms (Salehi et al., 2018). Morever, RSV is well known as antioxidant, anti-inflammatory, anti-aging and anti-carcinogenic compound with vast number of benefits and applications in research, treatments and clinical trials in medical fields (Salehi et al.).

This article aims at finding out the ameliorative effect of resveratrol against the cytotoxic effects of cigarette and waterpipe tobacco smoking by investigating the histopathological alterations in lung using light and electron microscopy techniques.

\section{MATERIAL AND METHOD}

Resveratrol (RSV). Trans-RSV was purchased from SigmaAldrich (USA). The purity of RSV was $99.65 \%$ HPLC. The daily dose of RSV was ( $25 \mathrm{mg} / \mathrm{kg} /$ day) according to Kandil et al., (2017). Phosphate buffer saline (PBS), $(0.1 \mathrm{M}$, pH 7.2) was used as vehicle during preparation of working solution.

The Cigarettes. Red labeled (L\&M) mark cigarettes were purchased from available local markets (Philip Morris, Jordan). Packet cover listed magnitude of some ingredient in each cigarette $(10 \mathrm{mg}$ tar, $0.8 \mathrm{mg}$ nicotine and $10 \mathrm{mg}$ $\mathrm{CO})$.

Tobacco honeyed-maassal and waterpipe preparation: Honeyed-Maassal was purchased from available local markets (Two Apples Flavored Molasses, Mazaya, Jordan). Packet cover did not illustrate the concentrations of all its ingredients (Tobacco, Molasses, Glycerine, Flavours and $0.05 \%$ nicotine). Five grams of maassal was uploaded to waterpipe head and the vase was half filled with tape water. For burning tobacco, one fast lighting disk $40 \mathrm{~mm}$ charoal was burned upon a perforated aluminium foil covering the waterpipe head.

Experimental animals. This study was operated according to instructions of the Scientific Committee in the School of Science at the University of Jordan in terms of animal handling and care. These instructions are consistent with the NIH guide for the care and use of laboratory animals 2011. Male albino BALB/c mice were chosen as animal model to perform this study. Mice were purchased from (Animal household / The University of Jordan). All adult males were aged of about eight weeks, weight $22 \pm 3$ grams. Forty-eight mice were divided randomly into 6 experimental groups; each group contains 8 mice. Group (Control): Mice were exposed to fresh air only. Group (RSV): Mice injected with
$0.2 \mathrm{ml}$ of RSV, interperitoneally (IP). Group (CS): Mice were exposed to cigarette smoking. Group (CS+RSV): Mice were exposed to CS and $0.2 \mathrm{ml} \mathrm{RSV,} \mathrm{(IP)} \mathrm{injection.} \mathrm{Group} \mathrm{(WPS):}$ Mice were exposed to waterpipe smoking. Group (WPS+RSV): Mice were exposed to WPS and $0.2 \mathrm{ml} \mathrm{RSV \text {, }}$ (IP) injection.

This experiment was performed and repeated daily on all animal groups for six consecutive weeks. Mice lived inside clean plastic cages. Cages were enclosed with fenestrated stainless-steel locked cover, open access to animal chew as feeding material with ad libitum for drinking water. Mice were acclimatized for one week prior starting the experiment, and lived-in well-ventilated room at room temperature with 12/12-hour day/night period.

Smoking exposure. Each group of mice exposed to tobacco smoking (cigarette or waterpipe) was placed inside transparent plexiglass box $(0.6 \times 0.5 \times 0.1 \mathrm{~m} 3)$ acting as inhalation chamber to perform a smoking process using modified smoking machine described by Shraideh et al., (2011b). Two cigarettes were lit for each cigarette smoking group (CS and CS+RSV), whereas one waterpipe head uploaded with 5 grams of tobacco honeyed-maassal was used for both waterpipe smoking groups (WPS and WPS+RSV). After placing mice inside the inhalation chamber, a vacuum pump withdraws smoke from lightened cigarette inside the chamber to provide a smoky environment for cigarette groups (each group was exposed individually to prevent mixing). Smoking procedure was 15 minutes in duration with 15 smoking intervals (10 seconds cigarette smoking puff + 50 seconds stop puffing with adequate ventilation), each cigarette was consumed within 7.5 minutes. The same procedure, generated air volume, duration and smoking intervals of cigarette groups were applied on waterpipe groups too (WPS and WPS+RSV). The same waterpipe head, uploaded tobacco honeyed maassal and charcoal were used for both waterpipe groups. It is important to mention that RSV solution was IP injected to mice of groups (4 and 6) using disposable insulin syringes before one hour from starting the smoking process.

Tissue fixation. The mice were euthanized by physical cervical dislocation. This process was done at the end of 6th week of the exposure. Mice were dissected to obtain the lungs. The lungs were washed with PBS and fixed in $10 \%$ formal saline for light microscopy or $2.5 \%$ glutaraldehyde in PBS for electron microscopy techniques.

Light Microscopy. The following techniques were performed according to Suvarna et al., (2018). Lung samples were dehydrated with ascending concentrations of ethanol, cleared with xylene alcohol, impregnated with melted 
paraffin wax, embedded in paraffin, and sectioned using manual rotary microtome (Leica RM2125RT, Leica Biosystems, Germany). staining with hematoxylin (HEMHP-OT-1L, BioGnost, Croatia) for 15 minutes, and eosin Y $0.2 \%$ aqueous (EOY-02-OT-1L, BioGnost, Croatia) for 5 minutes, mounted DPX, and microphotographed by (Leica inverted light microscopy, Leica Microsystems, Germany) installed with colored digital camera (Leica EC3, Switzerland) and monitored manually by computer software (Leica Application Suite LAS EZ version 1.8.0, Leica Microsystems, Switzerland).

Transmission electron microscopy. Pieces of $(1 \mathrm{~mm} 3)$ from the lungs of all treatment groups were fixed in $2.5 \%$ glutaraldehyde in PBS (0.1 M, pH 7.2) at $4 \mathrm{oC}$ in glass vials for 72 hours. Lungs were processed according to Battah et al., (2016). Samples were post-fixed with $1 \%$ osmium tetroxide (OsO4) in PBS (RT 19152, Electron Microscopy Sciences, Germany) for one hour at room temperature. Dehydration was carried by using gradual ascending concentrations of ethanol. The tissues were cleared by pure propylene oxide (110205, Sigma Aldrich, USA) with continuous rotation for 30 minutes, and then infiltrated with 1:1 propylene oxide: epoxy resin mixture with continuous rotation at room temperature for at least 3 hours. Next, the specimens were infiltrated overnight in pure epoxy resin with rotation at room temperature. Epoxy resin was prepared according to kit instructions (44610 DurcupanTM ACM, Sigma Aldrich, USA). Eventually, the tissues blocks were embedded in conical beem embedding capsules with pure epoxy resin and polymerized for 24 hours in oven at $60 \mathrm{oC}$. Golden ultrathin sections $(70 \mathrm{~nm})$ were prepared using diamond knife (DiATOME Ultra Diamantesser 45o, Switzerland) installed on ultramicrotome (Leica EM UC7, Leica MicroSystems, Germany). The ultrathin sections were mounted on copper grids (200 mesh grids, each about $97 \mu \mathrm{m}$ ) and stained with uranyl acetate and counter-stained with lead citrate. The grids were examined using transmission electron microscope (Morgagni 268, FEI Philips, Netherlands), monitored through computer software (Morgangi 268D Version 2.21, Netherlands). The ultrathin sections were photographed at 60 kilovolts at different magnifications.

\section{RESULTS}

The control group showed well intact epithelial cells lining the bronchioles, alveolar ducts were obvious and distinguishable, blood vessels characterized by normal endothelial cells and no dilations were seen in smooth muscles (Fig. 1A). The spaces of alveolar sacs were regu- lar, the alveoli were well inflated without deteriorations, alveolar septa were integral (Fig. 1B). RSV group showed almost the same histological features of the control group. The epithelial lining of bronchioles was intact and blood vessels showed normal endothelial lining (Fig. 1C). Alveolar sacs were normally inflated and having normal alveolar epithelial cells (Fig. 1D).

The CS group showed partial disruption of the epithelial lining of bronchioles with some blebs in the bronchiole lumen. Alveolar ducts were distinguishable (Fig. 1E). Extravasated red blood cells (RBCs) were highly diffused, blood vessels were dilated, congested and showed some dysfunction of endothelial cells and thickening of the walls characterized by non-cellular, amorphous, eosinophilic deposits in smooth muscles (Fig. 1E). Infiltrations of inflammatory cells were more obvious at the peripheral alveoli (near visceral pleura) than the parenchymal alveoli. Spaces of alveolar sacs were reduced due to non-proper inflation of alveoli and the alveoli were deflated (atelectasis) and displayed thickness in their alveolar walls with the disintegration of the alveolar septum (Fig. 1F). CS+RSV group shared some histopathological features of CS group, except: Epithelial cells of bronchioles were intact (Fig. 1G), the alveoli were more inflated, alveolar sac spaces were slightly larger, fewer infiltrations of inflammatory cells, less thickening in alveolar epithelial walls (Fig. 1H).

The WPS group showed massive disruption of the epithelial lining of bronchioles with distinct membrane blebs protruding toward bronchiole lumen and the alveolar ducts were highly deteriorated (Fig. 1I). Spaces of alveolar sacs were reduced due to non-proper inflation and thickening of alveoli. Some alveolar sacs contained thin cytoplasmic films of eosinophilic substances and yellow deposits resulted from the diffusion of the pulmonary hemosiderin protein (Fig. 1J). The alveoli were deflated (atelectasis) and displayed thickening in their walls with disintegration of the alveolar septum. Blood vessels were dilated and congested, endothelial cells showed dysfunction in their structure, RBCs were extravasated, thickening of the epithelial wall, eosinophilic non-cellular deposits in smooth muscles and some blood vessels were surrounded by multiple small pulmonary necrotic foci of inflammatory cells (Fig. 1I,J). In comparison with WPS group, WPS+RSV group showed less distortion of bronchiole epithelium with less apical membrane blebbing, and the alveolar ducts were recognizable (Fig. 1K). Alveolar sacs appeared more inflated, less thickening in alveolar epithelium, alveoli were more inflated, and less infiltration of inflammatory cells and hemosiderin deposits were significantly decreased (Fig. 1L). 
- trans RSV
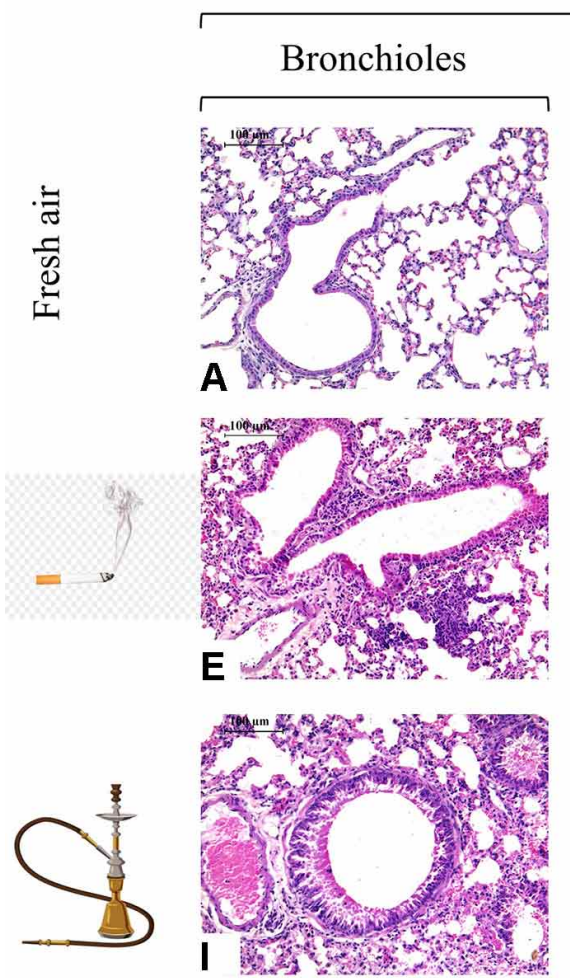
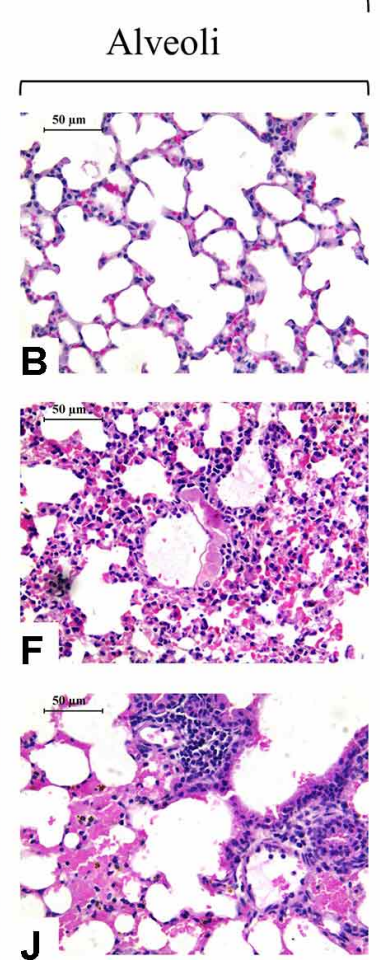

+ trans RSV

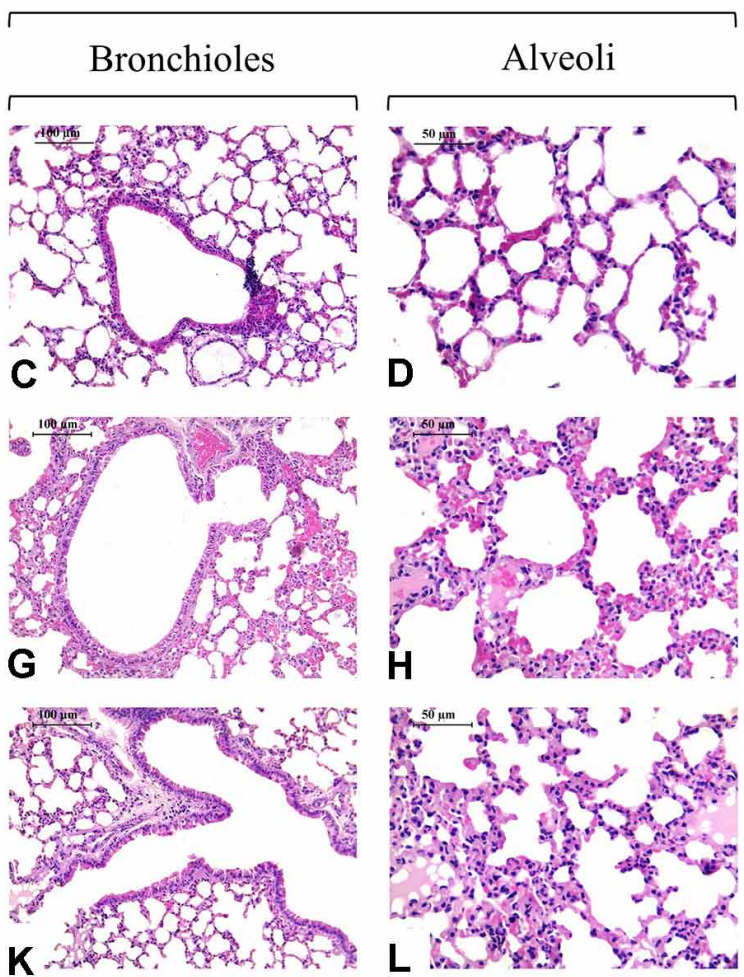

Fig. 1. Thin sections of $5 \mu \mathrm{m}$ for the lungs of different experimental groups. (A-B) represents the control group, (C-D) resveratrol, (E-F) cigarette smoking, (G-H) cigarette smoking + resveratrol, (I-J) waterpipe smoking, (K-L) waterpipe smoking + resveratrol. Sections were stained with hematoxylin and eosin; photomicrographs under low magnification half tick-down line have X200 magnification with scale bar of $100 \mu \mathrm{m}$; photomicrographs under higher magnification half tick-down line have X400 magnification with scale bar of $50 \mu \mathrm{m} ; \mathrm{n}=8$.

Ultrathin sections of control group were displayed normal structure of alveolar type II cells with euchromatic nuclei (Fig. 2A). Higher magnifications illustrate normal double layer membranes of mitochondria with normal rough endoplasmic reticulum (Fig. 2B). Ultrathin sections of RSV treatment group showed normal inflation of alveolar epithelial cells, euchromatic nuclei and normal mitochondrial structure (Fig. 2C-D). The ultrastructure of CS group showed thickening of alveolar wall compared to control (Fig. 2E). This thickness was at the expense of alveolar space. Some cells were entirely degenerated, thickening of the alveolar septum, pneumocytes type 2 were swollen and increased in number, blebbing of the apical membranes of alveolar epithelial cells. In higher magnifications, mitochondria were reduced in number and appeared pleomorphic with dilated cristae (Fig. 2F). It was noticed that both types of alveolar epithelium (I and II) had heterochromatic nuclei with some vacuolization in the cytosol. Ultrastructure of the alveolar septum in CS+RSV treatment showed mild structural changes of the epithelial cells (Fig. 2G). Degeneration, vacuolization, inflammatory marks and heterochromatic nuclei were all reduced. Higher magnifications showed uniform mitochondria with normal cristae (Fig. 2H). The apical epithelial membrane showed less fragmentations of blebs protruding into the pulmonary lumen in compared to CS group.

Ultrastructural sections of lungs of WPS treatment group showed deteriorations in the alveolar septa with high degree of epithelial degeneration, Spherical bulky bulges were well observed in alveolar lumen resulted from pinchedoff blebs of the apical epithelial membrane with thickening in alveolar septa (Fig. 2I). The remaining intact epithelial cells showed high vacuolization inside the cytosol, disruption of lamellar bodies of pneumocytes II, dilation of endoplasmic reticulum and pleomorphic mitochondria and heterochromatic nuclei (Fig. 2J). Ultrastructural sections of WPS+RSV treatment showed slight degeneration in alveolar epithelium, euchromatic nuclei with slight chromatin condensation, membranes of mitochondria were more intact, slight cytoplasmic vacuolization and thickening in alveolar walls (Fig. 2K-L). Rough endoplasmic reticulum was not dilated, and alveolar walls showed slight apical membranous blebbing. 


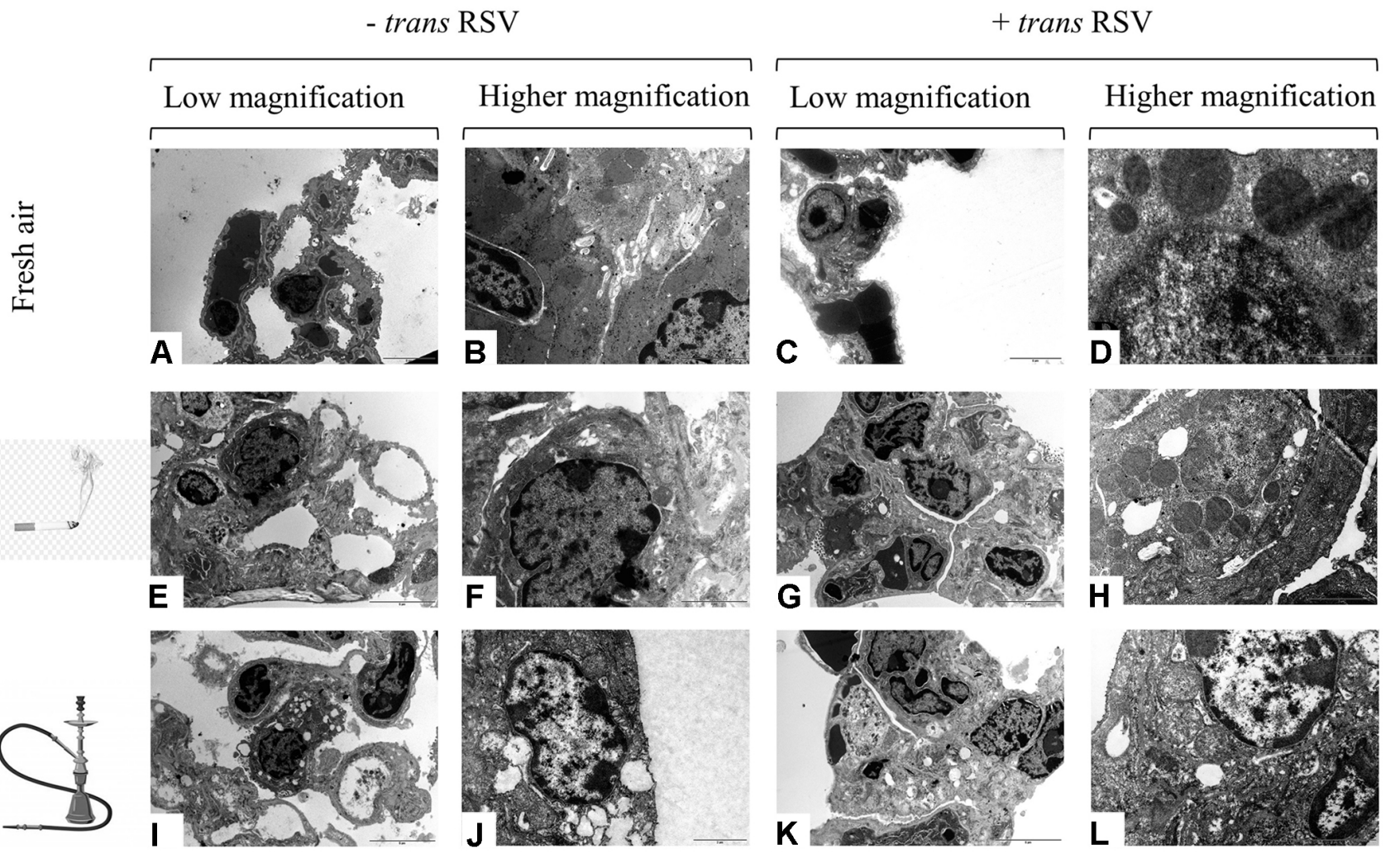

Fig. 2. Ultrathin sections of $70 \mathrm{~nm}$ from lungs of different experimental groups. (A-B) control group, (C-D) resveratrol, (E-F) cigarette smoking, (G-H) cigarette smoking + resveratrol, (I-J) waterpipe smoking, (K-L) waterpipe smoking + resveratrol. Sections were stained with uranyl acetate and counter-stained with lead citrate; electron micrographs under low magnification half tick-down line have scale bar of $5 \mu \mathrm{m}$; electron micrographs under higher magnification half tick-down line have scale bar of $2 \mu \mathrm{m}$, except figure (D) has scale bar of $1 \mu \mathrm{m} ; \mathrm{n}=8$.

\section{DISCUSSION}

The current study showed that cigarette and waterpipe tobacco smoking have deleterious effects on the bronchiolar and alveolar tissues of the lungs; they showed disruption of bronchiole epithelium with some apical membrane blebbing, deterioration of alveolar duct, incomplete inflation of alveolar sac, thickening of alveolar walls, infiltration of inflammatory cells, erythrocytes extravasation and dilation of blood vessels with non-cellular eosinophilic thickening in the smooth muscle fibers. This study illustrated that cigarette and waterpipe smoking promote the release of proteinaceous debris in the alveolar sacs. Also, this study illustrated that the ultrathin sections of lungs in the cigarette and waterpipe smoking exhibit alveolar degeneration, thickening of alveolar wall, formation of collagen fibers, apical membrane blebbing, cytoplasmic vacuolization, pleomorphic mitochondria and heterochromatic nuclei of alveolar epithelium. It is well known that cigarette and waterpipe smoking have harmful and toxic effects on pulmonary tissues.
Previous studies showed that the cigarette smoking causes thickening in alveolar walls, deterioration in alveolar septum, collapse of alveoli, congested blood vessels with extravasated erythrocytes, protein debris in alveolar airspace and infiltration of inflammatory cells (D'hulst et al., 2005; Shraideh et al., 2013; Itoh et al., 2014). Blebbing of apical membrane of alveolar epithelium could be caused by destruction of mitochondrial structure and consequent depletion of ATP production. Destruction of mitochondrial structure which results in depletion of ATP production causes cellular vacuolization and even plasma membrane blebbing (Battah et al.,).

Previous studies showed that impeding or impairment of mitochondrial function by anoxia causes cytoplasmic vacuolization and plasma membrane blebbing (Maltese \& Overmeyer 2014; Galluzzi et al., 2018). Waterpipe smoking showed almost the same histopathological features of cigarette smoking on lung with more exaggerated results (Shraideh et al., 2011a; Nemmar et al., 2018). 
Results of light microscopy of this study showed that RSV partially ameliorates the cytotoxicity of cigarette and waterpipe smoking. It has reduced the deterioration and blebbing of bronchiole epithelium, reduced the infiltration of inflammatory cells, increased the surface area of alveolar sac, reduced the thickening of alveolar walls and alveoli showed a sort of inflation. Also, blood vessels were less congested, dilated with less diffusion of extravasated blood. RSV has diminished hemosiderin diffusion induced by the cytotoxicity of waterpipe smoking in alveolar sacs.

Ultrastructural findings of lung in this study showed that RSV has partial protective role on alveolar cells against the cytotoxicity of cigarette and waterpipe smoking. RSV protects the normal structure of alveolar septum, prevents DNA damage and alveolar degeneration. Also, RSV treated groups showed less thickening in alveolar walls and less degree of apical membrane blebbing. Mitochondria were retaining the uniform pattern of their double membrane layers.

Previous studies illustrated that RSV has significantly decreased the level of protein oxidation in plasma by lowering the concentration of carbonyl content and increase the erythrocytic glutathione in mice induced by subchronic secondhand (passive) exposure of cigarette and waterpipe tobacco smoking (Alzbeede, 2019). Also, RSV has antiapoptotic effect against cigarette smoking extract and prevented the loss of mitochondrial membrane potential in vitro using human epithelial cell lines (Song et al., 2017). Moreover, RSV showed anti-oxidant and anti-inflammatory activities against nicotine (a toxic ingredient in cigarette and waterpipe smoking) induced lung injury in rats by reducing the concentration of inflammatory biomarkers like tumor necrosis factor alpha (TNF-a), interleukin-4 (IL-4) and interleukin-6 (IL-6) (Hamza \& El-Shenawy, 2017). In addition, RSV supplements has anti-inflammatory effect against multiple toxins, free radicals and oxidative stress conditions by decreasing the concentration of high sensitive C-reactive protein (hs-CRP), TNF-a and IL-6 (Koushki et al., 2018).

RSV has therapeutic effect on COPD mice model induced by cigarette smoking conjugated with lipopolysaccharides (a proinflammatory glycolipid in the cell wall of gram-negative bacteria); Oral administration of RSV using daily dose of $1 \mathrm{mg} / \mathrm{kg}$ or $3 \mathrm{mg} / \mathrm{kg}$ had protective and anti-inflammatory effect against acute exposure of cigarette smoking (Liu et al., 2014). RSV decreases the level of inflammatory cytokines like interleukin-17 (IL-17), IL-6, TNFa and transforming growth factor beta (TGF-b) (Chen et al., 2016). Recent reviews and current opinions have classified RSV as a promising therapeutic candidate against COPD and different lung cancer cell lines (Yousef et al., 2017; Beijers et al., 2018).
In conclusion, this study suggests that resveratrol antioxidant could has an ameliorative effect against the oxidative damage in the lung of mice induced by long term subchronic secondhand (passive) exposure of cigarette and waterpipe tobacco smoking. Smoking cessation is the best solution right now to eliminate the harmful of such inhaled toxins.

ACKNOWLEDGEMENTS. This work was supported by the Deanship of Scientific Research (Number 135/20162017), University of Jordan, Amman Jordan. The funders had no role in study design, data collection and analysis, decision to publish, or preparation of the manuscript. Thanks to Duaa Alqattan and Kholoud Friehat for their technical assistance. Also, thanks to Dr. Bashir Jarrar, Dr. Abdulkader Battah, and Dr. Hana Alebous for their suggestions and notes to improve the outcomes of this work.

ALZBEEDE, A. A.; SHRAIDEH, Z. A. \& BADRAN, D. H. Efecto paliativo del resveratrol frente a las alteraciones histológicas en el pulmón de ratones inducidas por exposición subcrónica del tabaquismo de cigarrillos y pipas de agua. Int. J. Morphol., 39(1):11-17, 2020.

RESUMEN: Este estudio tiene como objetivo evaluar la capacidad del antioxidante resveratrol (RSV) para atenuar el estrés oxidativo inducido por la exposición de segunda mano a los cigarrillos y al tabaquismo en pipa de agua, utilizando un modelo animal. Se dividieron cuarenta y ocho ratones en seis grupos diferentes, y se administró RSV a ciertos grupos por vía intraperitoneal con una dosis de $25 \mathrm{mg} / \mathrm{kg} /$ día. El proceso de exposición al tabaquismo se realizó utilizando una máquina de fumar especializada. La duración del experimento fue de seis semanas consecutivas. Para realizar la microscopía óptica se tiñeron secciones de pulmón de cinco $\mu \mathrm{m}$ con hematoxilina y eosina, y se prepararon secciones ultrafinas de $70 \mathrm{~nm}$ de pulmón teñidas con acetato de uranilo y citrato de plomo para la microscopía electrónica de transmisión para observar la ultra estructura celular. En el pulmón, el RSV redujo el deterioro y la formación de ampollas del epitelio de los bronquiolos, redujo la inflamación, aumentó la superficie del saco alveolar y redujo el engrosamiento de las paredes alveolares. Además, los vasos sanguíneos se encontraron menos congestionados y menos dilatados y con menor difusión de sangre extravasada. Las imágenes ultraestructurales mostraron que el RSV protege la estructura normal del tabique alveolar, previene el daño del ADN y la degeneración alveolar, mostrando un menor grado de formación de ampollas en la membrana apical y además retuvo el patrón uniforme de las mitocondrias. En conclusión, el RSV tiene efectos de mejora contra el estrés oxidativo inducido por la exposición de segunda mano (corriente secundaria) al fumar cigarrillos y pipas de agua.

PALABRAS CLAVE: Antioxidante; Microscopía; Histopatología; TEM; Tabaquismo. 


\section{REFERENCES}

Alzbeede, A. Ameliorating Effect of Resveratrol on Cigarette and Narghile Smoking Cytotoxicity in the Respiratory System of Albino Mouse: Histological and Biochemical Study. Unpublished Master Thesis. Amman, The University of Jordan, 2019.

Battah, K. A.; Badran, D. H. \& Shraideh, Z. A. Effect of cigarette smoking on the structure of hepatocytes: TEM study. Int. J. Morphol., 34(4):123944, 2016.

Beijers, R. J. H. C. G.; Gosker, H. R. \& Schols, A. M. W. J. Resveratrol for patients with chronic obstructive pulmonary disease: hype or hope? Curr. Opin. Clin. Nutr. Metab. Care, 21(2):138-44, 2018.

Chen, J.; Yang, X.; Zhang, W.; Peng, D.; Xia, Y.; Lu, Y.; Han, X.; Song, G.; Zhu, J. \& Liu, R. Therapeutic effects of resveratrol in a mouse model of LPS and cigarette smoke-induced COPD. Inflammation, 39(6):194959, 2016.

D’hulst, A. I.; Vermaelen, K. Y.; Brusselle, G. G.; Joos, G. F. \& Pauwels, R. A. Time course of cigarette smoke-induced pulmonary inflammation in mice. Eur. Respir. J., 26(2):204-13, 2005.

Dreher, D. \& Junod, A. F. Role of oxygen free radicals in cancer development. Eur. J. Cancer, 32A(1):30-8, 1996.

Galluzzi, L.; Vitale, I.; Aaronson, S. A.; Abrams, J. M.; Adam, D.; Agostinis, P.; Alnemri, E. S.; Altucci, L.; Amelio, I.; Andrews, D. W.; et al., Molecular mechanisms of cell death: recommendations of the Nomenclature Committee on Cell Death 2018. Cell Death Differ., 25(3):486-541, 2018.

Hamza, R. Z. \& El-Shenawy, N. S. Anti-inflammatory and antioxidant role of resveratrol on nicotine-induced lung changes in male rats. Toxicol. Rep., 4:399-407, 2017.

Itoh, M.; Tsuji, T.; Nakamura, H.; Yamaguchi, K.; Fuchikami, J. I.; Takahashi, M.; Morozumi, Y. \& Aoshiba, K. Systemic effects of acute cigarette smoke exposure in mice. Inhal. Toxicol., 26(8):464-73, 2014.

Kandil, Y. I.; Maraqa, A. D.; Oriquat, G. A. \& Shraideh, Z. A. Resveratrol pretreatment reduces circulating inflammatory interleukins in CCl4induced hepatotoxicity rats. Bull. Fac. Pharm. Cairo Univ., 55(2):31923, 2017.

Khani, Y.; Pourgholam-Amiji, N.; Afshar, M.; Otroshi, O.; Sharifi-Esfahani, M.; Sadeghi-Gandomani, H.; Vejdani, M. \& Salehiniya, H. Tobacco smoking and cancer types: A review. Biomed. Res Ther., 5(4):2142-59, 2018.

Koushki, M.; Dashatan, N. A. \& Meshkani, R. Effect of resveratrol supplementation on inflammatory markers: a systematic review and meta-analysis of randomized controlled trials. Clin. Ther, 40(7):11801192.e5, 2018.

Liu, H.; Ren, J.; Chen, H.; Huang, Y.; Li, H.; Zhang, Z. \& Wang, J. Resveratrol protects against cigarette smoke-induced oxidative damage and pulmonary inflammation. J. Biochem. Mol. Toxicol., 28(10):46571, 2014.

Maltese, W. A. \& Overmeyer, J. H. Methuosis: nonapoptotic cell death associated with vacuolization of macropinosome and endosome compartments. Am. J. Pathol., 184(6):1630-42, 2014.

Nemmar, A.; Al-Salam, S.; Yuvaraju, P.; Beegam, S. \& Ali, B. H. Exercise training mitigates water pipe smoke exposure-induced pulmonary impairment via inhibiting NF- $\mathrm{k}$ B and activating Nrf2 signalling pathways. Oxid. Med. Cell. Longev., 2018:7459612, 2018.

Phaniendra, A.; Jestadi, D. B. \& Periyasamy, L. Free radicals: properties, sources, targets, and their implication in various diseases. Indian J. Clin. Biochem., 30(1):11-26, 2015.

Salehi, B.; Mishra, A. P.; Nigam, M.; Sener, B.; Kilic, M.; Sharifi-Rad, M.; Fokou, P. V. T.; Martins, N. \& Sharifi-Rad, J. Resveratrol: a doubleedged sword in health benefits. Biomedicines, 6(3):91, 2018.

Shraideh, Z. A. \& Najjar, H. N. Histological changes in tissues of trachea and lung alveoli of albino rats exposed to the smoke of two types of narghile tobacco products. Jordan J. Biol. Sci., 4(4):219-24, 2011 a.
Shraideh, Z. A.; Awaida, W.; Najjar, H. \& Musleh, M. A modified smoking machine for monitoring the effect of tobacco smoke on albino rats. Jordan J. Biol. Sci., 4(2):109-12, 2011b.

Shraideh, Z.; Al-Awaida, W. \& Badran, D. Effects of cigarette smoking on histology of trachea and lungs of albino rat. Res. Opin. Anim. Vet. Sci., 3(10):356-62, 2013.

Song, C.; Luo, B. \& Gong, L. Resveratrol reduces the apoptosis induced by cigarette smoke extract by upregulating MFN2. PLoS One, 12(4): $0175009,2017$.

Suvarna, K.; Layton, C. \& Bancroft, J. D. Bancroft's Theory and Practice of Histological Techniques. $8^{\text {th }}$ ed. Philadelphia, Elsevier, 2018.

Yoshida, T. \& Tuder, R. M. Pathobiology of cigarette smoke-induced chronic obstructive pulmonary disease. Physiol. Rev., 87(3):1047-82, 2007.

Yousef, M.; Vlachogiannis, I. A. \& Tsiani, E. Effects of resveratrol against lung cancer: in vitro and in vivo studies. Nutrients, 9(11):1231, 2017.

\section{Corresponding author: \\ Darwish H. Badran}

Department of Anatomy and Histology

School of Medicine

The University of Jordan

Amman, 11942

JORDAN

\section{Email: dhbadran@ju.edu.jo}

Received: 22-07-2020

Accepted: 10-09-2020 